\title{
Impairment of Catecholamine Systems during Induction of Long-Term Potentiation at Hippocampal CA1 Synapses in HPC-1/Syntaxin 1A Knock-out Mice
}

\author{
Tatsuya Mishima, ${ }^{1}$ Tomonori Fujiwara, ${ }^{1}$ Takefumi Kofuji, ${ }^{2}$ and Kimio Akagawa ${ }^{1}$ \\ ${ }^{1}$ Department of Cell Physiology and ${ }^{2}$ Radio Isotope Laboratory, Kyorin University School of Medicine, Mitaka, Tokyo 181-8611, Japan
}

The membrane protein HPC-1/syntaxin $1 \mathrm{~A}$ is believed to play a key role in synaptic vesicle exocytosis, and it was recently suggested to be required for synaptic plasticity. Despite evidence for the function of HPC-1/syntaxin 1A in synaptic plasticity, the underlying cellular mechanism is unclear. We found that although fast synaptic transmission and long-term depression were unaffected, HPC-1/syntaxin 1A knock-out $\left(\mathrm{STX}_{\mathrm{A}} \mathrm{A}^{-1-}\right.$ ) mice showed impaired long-term potentiation (LTP) in response to theta-burst stimulation in CA1 hippocampal slices. The impairment in LTP was rescued by the application of forskolin, an adenylyl cyclase activator, or more robust stimulation, suggesting that cAMP/protein kinase A signaling was suppressed in these mice. In addition, catecholamine release from the hippocampus was significantly reduced in STX1A ${ }^{-1-}$ mice. Because HPC-1/syntaxin $1 \mathrm{~A}$ regulates exocytosis of dense-core synaptic vesicles, which contain neuromodulatory transmitters such as noradrenaline, dopamine and 5-HT, we examined the effect of neuromodulatory transmitters on LTP induction. Noradrenaline and dopamine enhanced LTP induction in STX1A ${ }^{-1-}$ mice, whereas catecholamine depletion reduced LTP induction in wild-type mice. Theses results suggest that HPC-1/syntaxin $1 \mathrm{~A}$ regulates catecholaminergic systems via exocytosis of dense-core synaptic vesicles, and that deletion of HPC-1/syntaxin 1A causes impairment of LTP induction.

\section{Introduction}

The plasma membrane proteins HPC-1/syntaxin 1A and syntaxin 1B (Inoue et al., 1992; Kushima et al., 1997) are isoforms of syntaxin 1 that have key regulatory roles in several synaptic functions in the CNS. For example, HPC-1/syntaxin 1A is a part of the machinery responsible for neurotransmission (Bennett et al., 1992). Neurotransmitter release is mediated by the soluble $N$-ethylmaleimide-sensitive fusion protein attachment protein receptor (SNARE) protein complex (Lin and Scheller, 2000; Rizo and Südhof, 2002), and HPC-1/syntaxin 1A forms a ternary SNARE protein complex by interacting with synaptosomalassociated protein of $25 \mathrm{kDa}$ (SNAP-25) and vesicle-associated membrane protein-2 (VAMP-2)/synaptobrevin. Inhibition of the SNARE complex assembly affects neurotransmitter release in vitro (Söllner et al., 1993; Yamaguchi et al., 1997; Xu et al., 1999; Fujiwara et al., 2001; Mishima et al., 2002), which suggests that HPC-1/syntaxin $1 \mathrm{~A}$ is necessary for neurotransmitter release. In addition, HPC-1/syntaxin $1 \mathrm{~A}$ interacts with $\mathrm{N}$ - and P/Q-type calcium channels and regulates their function (Bezprozvanny et

\footnotetext{
Received June 9, 2011; revised 0ct. 12, 2011; accepted Nov. 10, 2011.

Author contributions: T.M. designed research; T.M., T.F., and T.K. performed research; T.M., T.F., T.K., and K.A. contributed unpublished reagents/analytic tools; T.M. and T.F. analyzed data; T.M. wrote the paper.

This study was supported in part by a Grant-in-Aid for Scientific Research (C) from the Ministry of Education, Culture, Sports, Science and Technology (MEXT), Japan, to T.F. (no. 22500338); a Grant-in-Aid for Scientific Research (B) to K.A. (no. 19300133) from MEXT, Japan; and a Grant-in-Aid from the Promotion and Mutual Aid Cooperation for Private Schools of Japan to K.A.

The authors declare no competing financial interests.

Correspondence should be addressed to Tatsuya Mishima, Department of Cell Physiology, Kyorin University School of Medicine, Mitaka, Tokyo 181-8611, Japan. E-mail: mishimat@ks.kyorin-u.ac.jp.

DOI:10.1523/JNEUROSCI.2911-11.2012

Copyright $\odot 2012$ the authors $\quad 0270-6474 / 12 / 320381-09 \$ 15.00 / 0$
}

al., 1995; Mochida et al., 1996; Degtiar et al., 2000). The direct interaction of HPC-1/syntaxin $1 \mathrm{~A}$ or syntaxin $1 \mathrm{~B}$ with an $\mathrm{N}$-type calcium channel induces a negative shift in the half-inactivation potential of the channel (Bezprozvanny et al., 1995). Furthermore, HPC-1/syntaxin 1A, but not syntaxin $1 \mathrm{~B}$, inhibits $\mathrm{N}$-type calcium channel activity indirectly via $\mathrm{G}$-protein $\beta \gamma$ subunits in a voltage-dependent manner (Jarvis and Zamponi, 2001). Finally, HPC-1/syntaxin 1A modulates the activity of various plasma membrane-bound neuromodulator transporters, including noradrenaline (NA) transporters, serotonin (5-HT) transporters, and dopamine (DA) transporters (Sung et al., 2003; Quick, 2003, 2006; Carvelli et al., 2008). Given that hippocampal synaptic plasticity is strongly influenced by neuromodulatory transmitters (Otmakhova and Lisman, 1996; Katsuki et al., 1997), HPC-1/ syntaxin 1A may be closely related to synaptic plasticity.

Synaptic plasticity at hippocampal glutamate synapses can be expressed as the long-term potentiation (LTP) or depression of synaptic strength. In hippocampal Schaffer collateralcommissural CA1 synapses, LTP involves two mechanically distinct phases: early and late. Early LTP requires a postsynaptic calcium influx through $N$-methyl-D-aspartate receptors and the activation of $\mathrm{Ca}^{2+} /$ calmodulin-dependent protein kinase II; however, it does not require the activation of cAMP-dependent protein kinase A (PKA) or new protein synthesis (Lisman, 2003). In contrast, late LTP requires the activation of adenylyl cyclase and PKA (Nguyen and Kandel, 1997; Otmakhova et al., 2000). We previously reported that HPC-1/syntaxin 1A knock-out $\left(\mathrm{STX} 1 \mathrm{~A}^{-/-}\right.$) mice had impaired LTP in the CA1 area of the hippocampus based on an analysis of brain slices (Fujiwara et al., 2006). Also, consolidation of contextual fear memory was im- 
paired. In addition, 5-HT release from the hippocampus and hypothalamus was significantly reduced (Fujiwara et al., 2010) indicating a relationship between the above impairment of STX1A ${ }^{-1-}$ mice and neuromodulatory systems. To examine the cellular mechanisms responsible for this impairment in synaptic plasticity, we investigated the contribution of neuromodulators to synaptic plasticity.

\section{Materials and Methods}

Animals. C57BL/6 mice were used for all experiments unless otherwise indicated. The mice were kept under a $12 \mathrm{~h}$ light/dark cycle (lights on at 6:00 A.M.), and food and water were available ad libitum. STX1A ${ }^{-1-}$ mice were generated as previously described (Fujiwara et al., 2006). Most of the experiments were performed using littermate WT and STX1A ${ }^{-1-}$ mice.

Electrophysiology. Adult male mice (10-15 weeks old, weighing 25-30 g) were deeply anesthetized with diethyl ether and their brains were dissected. Parasagittal hippocampal slices ( $350 \mu \mathrm{m}$ thick) were obtained using a vibratome in ice-cold cutting solution containing (in $\mathrm{mm}$ ): 75 sucrose, $85 \mathrm{NaCl}, 25 \mathrm{NaHCO}_{3}, 2.5 \mathrm{KCl}, 1.25 \mathrm{NaH}_{2} \mathrm{PO}_{4}, 8 \mathrm{MgCl}_{2}, 0.5$ $\mathrm{CaCl}_{2}$, and 10 glucose. The slices were maintained for at least $2 \mathrm{~h}$ at room temperature in $95 \% \mathrm{O}_{2}$ and $5 \% \mathrm{CO}_{2}$-bubbled artificial CSF (ACSF) containing (in mM): $123 \mathrm{NaCl}, 25 \mathrm{NaHCO}_{3}, 2.5 \mathrm{KCl}, 1.25 \mathrm{NaH}_{2} \mathrm{PO}_{4}, 2 \mathrm{CaCl}_{2}$, $1 \mathrm{MgCl}_{2}$, and 10 glucose. In the recording chamber, the slices were continuously superfused with $95 \% \mathrm{O}_{2}$ and $5 \% \mathrm{CO}_{2}$-bubbled ACSF (2-3 $\mathrm{ml} / \mathrm{min}$ ). Schaffer collaterals were stimulated with a bipolar tungsten electrode, and field EPSPs (fEPSPs) were recorded from the stratum radiatum of the CAl area using glass pipettes containing $500 \mathrm{~mm} \mathrm{NaCl}$. Basal synaptic transmission was monitored at $0.05 \mathrm{~Hz}$. LTP was induced using theta-burst stimulation (TBS) as previously described (12 bursts at $5 \mathrm{~Hz}$, each consisting of four pulses delivered at $100 \mathrm{~Hz}$ ) (Patterson et al., 2001), which reliably induced late-phase LTP. The duration of the pulses was $0.1 \mathrm{~ms}$, and the stimulation strength was set to obtain an fEPSP with $35-40 \%$ maximal amplitude. The duration of the pulses was $0.1 \mathrm{~ms}$, and the stimulation strength was set to obtain an fEPSP with 50-60\% maximal amplitude. All drugs were purchased from Sigma-Aldrich, except clonidine hydrochloride, which was from Tocris Bioscience.

All data are presented as the means \pm SEM. Statistical significance was determined using one-way ANOVA and two-tailed Student's $t$ tests. To assess maintenance of LTP, the average size of the slope of fEPSPs recorded between 50 and 60 min after TBS was used for statistical comparisons by using one-way ANOVA with Dunnett's post hoc analysis compared with the WT control. Differences were considered significant at $p<0.05$.

Measurement of monoamine and their metabolites in hippocampal slices. Slices were snap-frozen in liquid nitrogen, and the tissue samples were homogenized by sonication in $0.2 \mathrm{~m}$ perchloric acid with $0.1 \mathrm{~mm}$ EDTA. The homogenate was kept on ice for $1 \mathrm{~h}$ and then centrifuged $(20,000 \times$ $\mathrm{g}, 20 \mathrm{~min}$ ). The supernatant was collected, and the $\mathrm{pH}$ was adjusted to 3.0 with acetic acid. The samples were then subjected to high-performance liquid chromatography, and NA, DA, 5-HT, the NA metabolite 3-methoxy, 4-hydroxyphenylglycol (MHPG), the DA metabolite dihydroxyphenylacetic acid (DOPAC) and the 5-HT metabolite 5-hydroxyindolacetic acid (5HIAA) were detected electrochemically (EICOM) as previously described (Fujiwara et al., 2001).

In vivo microdialysis. Male mice (12-15 weeks old) were anesthetized with $2.5 \%(\mathrm{v} / \mathrm{v})$ avertin $(0.02 \mathrm{ml} / \mathrm{g}$ body weight $)$ and then mounted onto a stereotaxic frame (Narishige). A guide cannula was implanted unilaterally in the left dorsal hippocampus $(\mathrm{A} / \mathrm{P},+1.0 ; \mathrm{L} / \mathrm{M},+1.3 ; \mathrm{D} / \mathrm{V}, 2.3)$ (Franklin and Paxinos, 1997), which was then fixed to the skull with dental cement. After surgery, mice were individually housed and allowed to recover for at least $7 \mathrm{~d}$ before being subjected to microdialysis. On the experimental day, a dialysis probe (membrane length $1 \mathrm{~mm}$; EICOM) was inserted into the guide cannula and perfused at a constant flow rate of $2 \mu \mathrm{l} / \mathrm{min}$ with Ringer's solution using a micro-syringe pump (EICOM). The mice were placed in a novel test chamber $(250 \times 300 \mathrm{~mm})$ where they were allowed to move freely and were habituated to the apparatus for at least 2-3 h. Dialysates were then collected (15 min/ fraction) and subjected to HPLC and monoamines were detected electrochemically (EICOM). Basal levels of monoamines were measured from 10 fractions before stimulation. The perfusion solution was then exchanged with high- $\mathrm{K}^{+}$solution $(100 \mathrm{~mm}$; isomolar replacement of $\mathrm{NaCl}$ with $\mathrm{KCl}$ ) for $30 \mathrm{~min}$. After stimulation, the perfusion solution was changed to normal Ringer's solution and monoamines were measured until they returned to basal levels. To quantify the basal level of extracellular monoamines concentrations in hippocampus, no-net-flux microdialysis was performed (Parsons and Justice, 1992). In brief, the mice which was inserted dialysis probe and was perfused at a constant flow rate of $2 \mu \mathrm{l} / \mathrm{min}$ with Ringer's solution, were placed in test chamber. After 2-3 $\mathrm{h}$, dialysates were collected ( $15 \mathrm{~min} /$ fraction) and baseline level of monoamines were measured. Thereafter, four concentrations $\left(C_{\text {in }} ; 0,0.1,0.3,1\right.$ $\mathrm{nm}$ ) of each monoamine in Ringer's solution were perfused through the probes at a random order. After $30 \mathrm{~min}$ of equilibration period, three fractions were collected for measurement of each monoamine $C_{\text {out }}$. A linear equation was constructed for each mouse by plotting the net-flux of monoamines through the dialysis probe $\left(C_{\text {in }}-C_{\text {out }}\right)$ against $C_{\text {in }}$. Based on this analysis, the extracellular monoamines concentrations were calculated as the perfusion fluid each monoamine concentrations at which there is no net flux of each monoamine through the probe $\left(C_{\text {in }}=C_{\text {out }}\right)$.

Catecholamine uptake and release assay in synaptosome. The analysis for catecholamine uptake and release were performed using synaptosomes as previously described (Fujiwara et al., 2010). In brief, the brains were homogenized in $0.32 \mathrm{M}$ sucrose, and the homogenate was centrifuged at $1000 \times g$ for $10 \mathrm{~min}$. The supernatant was centrifuged at $15,000 \times g$ for $20 \mathrm{~min}$, and the crude synaptosomal pellet was suspended in $0.32 \mathrm{~m}$ sucrose. The synaptosomal fractions were further purified via discontinuous sucrose gradient centrifugation at 53,000 $\times g$ for $120 \mathrm{~min}$. The purified synaptosomes were suspended in assay buffer $(135 \mathrm{~mm}$ $\mathrm{NaCl}, 5 \mathrm{~mm} \mathrm{KCl}, 0.3 \mathrm{~mm} \mathrm{KH}_{2} \mathrm{PO}_{4}, 2 \mathrm{~mm} \mathrm{MgSO}_{4}, 0.3 \mathrm{~mm} \mathrm{Na}_{2} \mathrm{HPO}_{4}, 1.2$ $\mathrm{mm} \mathrm{CaCl}_{2}, 10 \mathrm{~mm}$ glucose, $10 \mathrm{~mm}$ HEPES, $\mathrm{pH}$ 7.4). The purified synaptosomes $(50 \mu \mathrm{g})$ were incubated with $0.05-100 \mu \mathrm{M}$ of $\left[{ }^{3} \mathrm{H}\right] \mathrm{DA}$ or $-\mathrm{NA}$ at $37^{\circ} \mathrm{C}$ for $30 \mathrm{~min}$, respectively. After the uptake period, the synaptosomes were washed three times and resuspended in assay buffer. Radioactivity was counted by liquid scintillation counting. Nonspecific $\left[{ }^{3} \mathrm{H}\right] \mathrm{NA}$ uptake was defined as the counts at each NA concentration in the presence of $1 \mu \mathrm{M}$ desipramine, a specific inhibitor of the NA transporter, and was subtracted from the total uptake. Nonspecific $\left[{ }^{3} \mathrm{H}\right] \mathrm{DA}$ uptake was defined as the counts at each DA concentration in the presence of $1 \mu \mathrm{M}$ GBR12909, a specific inhibitor of the DA transporter, and was subtracted from the total uptake. To quantify $\left[{ }^{3} \mathrm{H}\right] \mathrm{DA}$ or -NA release from the synaptosomes, the synaptosomes $(50 \mu \mathrm{g})$ were incubated with $2.5 \mu \mathrm{M}$ of $\left[{ }^{3} \mathrm{H}\right] \mathrm{DA}$ or $-\mathrm{NA}$ at $37^{\circ} \mathrm{C}$ for $30 \mathrm{~min}$, respectively. After the uptake period, the synaptosomes were washed three times and resuspended in assay buffer. The synaptosomes were induced in assay buffer at $37^{\circ} \mathrm{C}$ for $30 \mathrm{~min}$ (basal release) or were stimulated with $15 \mathrm{~mm} \mathrm{KCl}$ containing assay buffer $(15 \mathrm{~mm} \mathrm{~K})$. After the stimulation, radioactivity of the release from the synaptosomes and remaining in the synaptosomes were counted. The amount released was calculated as a percentage of the total radioactivity (the sum of the remaining and released $\left[{ }^{3} \mathrm{H}\right] \mathrm{DA}$ or $-\mathrm{NA}$ ). Uptake data were analyzed using the iterative nonlinear fitting software WaveMetrics IGOR Pro 6.0.

\section{Results}

Synaptic transmission in HPC-1/syntaxin 1A knock-out mice We previously reported that fast synaptic transmission in cultured hippocampal neurons remained unchanged in STX1 $\mathrm{A}^{-1-}$ mice. However, our previous study showed that mice exhibited impaired LTP in the CA1 region in hippocampal slices (Fujiwara et al., 2006). Thus, we first confirmed the basal synaptic properties of hippocampal slices from STX1A ${ }^{-1-}$ mice to determine the effect of the deletion of HPC-1/syntaxin 1A. The presynaptic fiber volley amplitude and initial fEPSP slope were measured in the CA1 region of several hippocampal slices using a range of stimulus intensities. The resulting input-output curves, which represent the relationship between the amplitude of the afferent fiber 

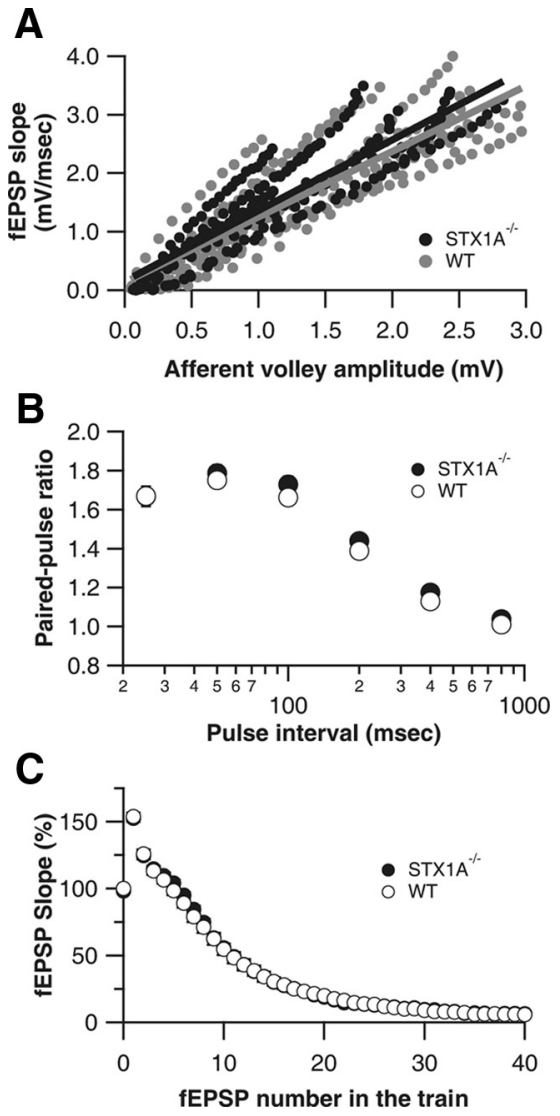

Figure 1. Basic synaptic transmission in STX1A ${ }^{-1-}$ mice. $\boldsymbol{A}$, Input- output curves. The slope of fEPSP is plotted as a function of the afferent fiber volley amplitude. The linear fit slopes were not significantly different between WT $(n=10)$ and STX1A ${ }^{-1-}$ mice $(n=8)$. $\boldsymbol{B}$, The paired-pulse ratio (fEPSP2/fEPSP1) at various interpulse intervals was not significantly different between WT $(n=19)$ and STX1A ${ }^{-1-}$ mice $(n=17)$. C, The response to a $50-H z$ stimulus train was not significantly different between WT $(n=13)$ and STX1A ${ }^{-1-}$ mice $(n=6)$.

volley and the resulting fEPSPs, were similar between the WT and STX1A $^{-1-}$ mice (Fig. 1A). Paired-pulse facilitation (PPF) using the ratios of the second and first fEPSP slopes at various interpulse intervals was measured to evaluate the effects of the deletion of HPC-1/syntaxin 1A on the probability of transmitter release in the hippocampal slices. As shown in Figure $1 B$, no significant difference in PPF was observed between the WT and STX1A ${ }^{-1-}$ mice. We also examined the temporal pattern of synaptic responses during repetitive stimulation of Schaffer collaterals at a relatively high frequency $(50 \mathrm{~Hz})$. Repetitive stimulation led to an initial facilitation followed by depression, but no significant difference was detected between WT and STX1A ${ }^{-1-}$ mice (Fig. 1C).

\section{Synaptic plasticity in STX1 $\mathrm{A}^{-/-}$mice}

To determine the effects of the loss of HPC-1/syntaxin 1A on synaptic plasticity, we analyzed LTP. After recording the stable baseline responses, LTP was induced by TBS of the Schaffer collaterals. TBS produced post-tetanic potentiation in all of the slices (Fig. 2A). The maximum value of post-tetanic potentiation within the first 2 min after TBS was $253.9 \pm 9.0 \%$ for WT mice and $230.1 \pm 8.9 \%$ for STX1A ${ }^{-1-}$ mice. No significant difference was observed in the level of post-tetanic potentiation $(p>0.1)$. The level of LTP at 50-60 min post-TBS was $175.9 \pm 2.2 \%$ for WT mice and $143.1 \pm 4.2 \%$ for STX1A ${ }^{-1-}$ mice. LTP decreased significantly in STX1A ${ }^{-/-}$mice $(p<0.01)$. To confirm whether the reduction in LTP was influenced by a shift in the release
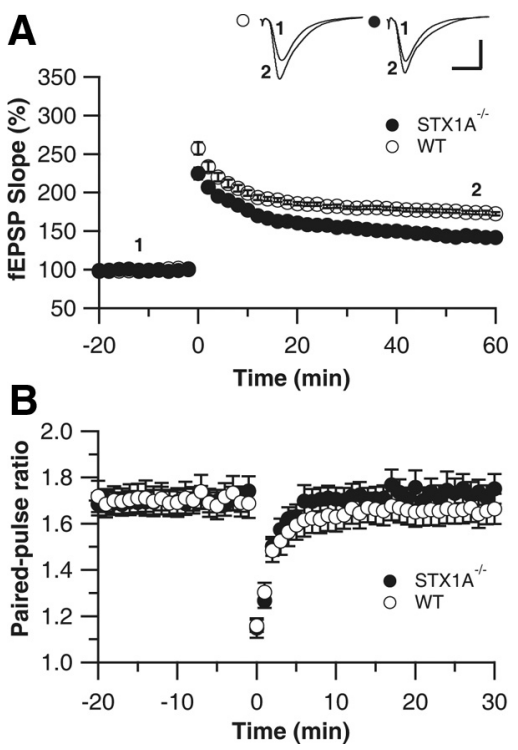

Figure 2. Hippocampal synaptic plasticity in the CA1 area in STX1A ${ }^{-/-}$mice. $\boldsymbol{A}$, LTP elicited by TBS, decreased significantly in STX1A ${ }^{-1-}$ mice $(n=15)$ compared with WT mice $(n=24)$. The mean slope of the fEPSP recorded 0-20 min before TBS was taken as 100\%. Insets, Representative field EPSPs before and after TBS stimulation are shown. Calibration: $10 \mathrm{~ms}, 1 \mathrm{mV}$. $\boldsymbol{B}$, Paired-pulse ratio at an interpulse interval of $50 \mathrm{~ms}$. LTP induction was not accompanied by a shift in transmitter release probability after TBS at time $0 \mathrm{~min}$. The paired-pulse ratio was not significantly different between WT $(n=19)$ and STX1A ${ }^{-1-}$ mice $(n=19)$ after LTP induction.

probability after TBS, PPF at an interpulse interval of $50 \mathrm{~ms}$ was measured (Fig. 2B). PPF was not significantly different between WT and STX1A ${ }^{-1-}$ mice even after LTP induction $(p>0.2)$.

\section{Reduced hippocampal LTP could be rescued by forskolin or robust synaptic stimulation}

Late-phase LTP induced by TBS requires an elevation in cAMP and the activation of PKA (Nguyen and Kandel, 1997). We investigated whether pharmacological activation of adenylyl cyclase during TBS could enhance LTP induction and maintenance. Bath application of forskolin (Fsk; $10 \mu \mathrm{M}$ ), an adenylyl cyclase activator, beginning $15 \mathrm{~min}$ before the induction of LTP restored LTP induction and maintenance in STX1 $\mathrm{A}^{-1-}$ mice to the levels observed in WT mice $(p>0.6)$ (Fig. 3A). Even so, Fsk did not further enhance LTP in WT mice $(p>0.9)$. At the concentration used here $(10 \mu \mathrm{M})$, Fsk alone did not cause lasting potentiation as compared with the baseline in either WT or STX1A ${ }^{-1-}$ mice.

In this study, we used 12 bursts of TBS, which is sufficient to induce near maximal LTP (Arai and Lynch, 1992). To confirm the possibility that the reduction in LTP in STX1A ${ }^{-1-}$ mice was caused by a rise in the stimulus strength required for the induction of LTP, more robust stimulation was used to induce LTP. Specifically, 12 bursts of TBS were provided twice at 20 -s intervals (Fig. 3B). In WT mice, this protocol did not cause enhanced potentiation $(p>0.8)$, suggesting that 12 bursts of stimulation are sufficient to induce maximal LTP. The protocol, however, facilitated LTP induction and maintenance in STX1 $\mathrm{A}^{-/-}$mice to the levels seen in the WT mice $(p>0.6)$. The bath application of KT5720 $(1 \mu \mathrm{M})$, a selective inhibitor of PKA, to hippocampal slices from STX1A ${ }^{-1-}$ mice reverted facilitated LTP induced by the robust stimulus protocol $(p<0.05)$ (Fig. 3C). KT5720 also decreased LTP in WT mice induced by the robust stimulus protocol $(p<0.05)$. These results suggest that the cAMP/PKA signaling cascade did not function normally when 12 bursts of 
A
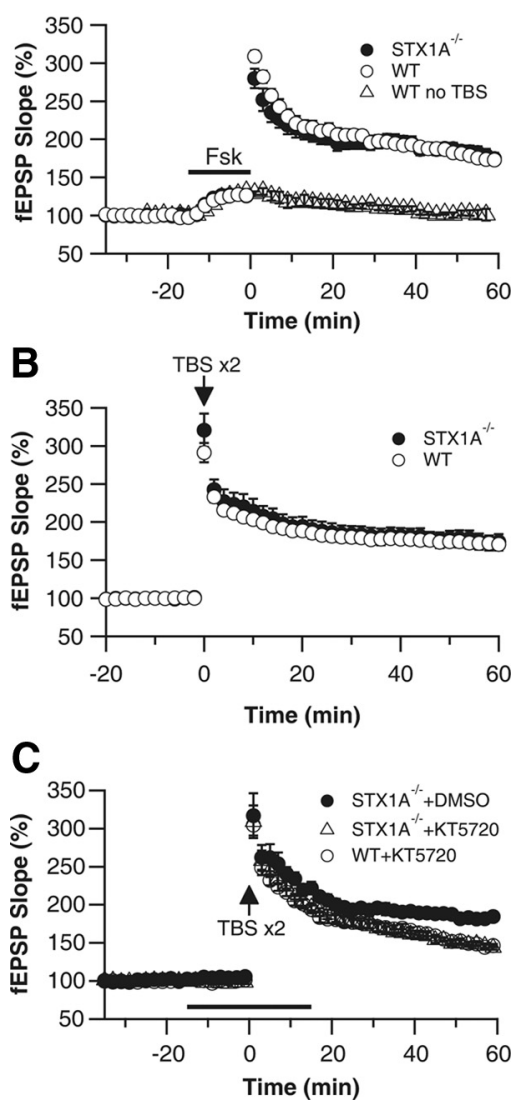

Figure 3. Effect of Fsk and robust presynapticstimulation on LTP. A, In STX1A ${ }^{-1-}$ mice, Fsk, an adenylyl cyclase activator, rescued LTP induction and maintenance to levels seen in WT mice ( $n=12$ ). Fsk was bath-applied for $15 \mathrm{~min}$ before LTP induction. Fsk alone did not elicit lasting potentiation $(n=3)$. In WT mice, Fsk did not further enhance LTP $(n=9)$. The mean slope of fEPSPs recorded $0-20$ min before the application of Fsk was taken as $100 \%$. B, Robust presynaptic stimulation (arrow: 12 bursts of TBS provided twice at 20-s intervals) rescued LTP induction and maintenance to levels seen in WT mice $(n=16)$. In WT mice, the protocol did not result in enhanced potentiation $(n=10)$. The mean slope of fEPSPs recorded $0-20 \mathrm{~min}$ before TBS was taken as $100 \%$. C, The application of $1 \mu \mathrm{m}$ KT5720, a selective inhibitor of PKA, to the bath solution reverted rescued LTP induction by robust presynaptic stimulation (arrow) in STX1A ${ }^{-1-}$ mice $(n=6)$. KT5720 also decreased LTP induced by the robust presynaptic stimulation in WT mice $(n=4)$. The application of DMSO alone had no effect on STX1A ${ }^{-1-}$ mice $(n=4)$.

stimulation was provided at the synapse in the hippocampal CA1 region in STX1A $\mathrm{A}^{-1-}$ mice.

\section{Effect of monoamine on LTP induction and maintenance}

We previously reported that in STX1A ${ }^{-1-}$ mice, though the content of 5-HT was significantly increased in the hippocampus, 5-HT release from hippocampal slices was significantly reduced (Fujiwara et al., 2010). Because HPC-1/syntaxin 1A is widely accepted to regulate exocytosis of synaptic vesicles, it is possible that release of other monoaminergic neuromodulatory transmitters is also reduced. There is cumulative evidence that neuromodulatory transmitters, including monoaminergic systems, are involved in the induction of LTP (Staubli and Otaky, 1994; Schimanski et al., 2007). In particular, NA and DA are keymodulators of LTP induction via activation of the cAMP/PKA signaling cascade.

To determine the involvement of monoaminergic neuromodulators in LTP impairment, we examined the amount of
Table 1. Monoamines and their metabolite contents in hippocampus

\begin{tabular}{lll}
\hline & WT $(n=16)$ & STX1A $^{-1-}(n=6)$ \\
\hline NA (ng/mg protein) & $4.56 \pm 0.64$ & $3.52 \pm 1.07$ \\
MHPG (ng/mg protein) & $0.44 \pm 0.04$ & $0.37 \pm 0.12$ \\
MHPG/NA & $0.09 \pm 0.01$ & $0.13 \pm 0.03$ \\
DA (ng/mg protein) & $2.47 \pm 0.33$ & $3.57 \pm 0.72$ \\
DOPAC (ng/mg protein) & $1.17 \pm 0.12$ & $0.86 \pm 0.16$ \\
DOPAC/DA & $0.37 \pm 0.03$ & $0.19 \pm 0.03^{* *}$ \\
5-HT (ng/mg protein) & $5.74 \pm 0.36$ & $8.23 \pm 0.40^{* *}$ \\
5-HIAA (ng/mg protein) & $1.42 \pm 0.30$ & $1.21 \pm 0.10$ \\
5-HIAA/5-HT & $0.25 \pm 0.05$ & $0.15 \pm 0.01$ \\
\hline
\end{tabular}

Data shown are mean \pm SE. ${ }^{* *} p<0.01$.

three monoaminergic neuromodulatory transmitters (NA, DA, and 5-HT), and their metabolites (MHPG, DOPAC, and 5-HIAA) in hippocampal slices from each genotype (Table 1). As previously reported, the amount of 5-HT was significantly increased in hippocampal slices of STX1A ${ }^{-1-}$ mice, while the amount of NA, DA, MHPG, DOPAC, and 5-HIAA was not different among genotypes. Although MHPG/NA ratio and 5-HIAA/5-HT ratio were unchanged, the DOPAC/DA ratio was decreased in STX1A ${ }^{-1-}$ mice, indicating a decrease in turnover of DA. In addition, we also used in vivo microdialysis to measure monoamine release induced by high- $\mathrm{K}^{+}$stimulation (Fig. 4). Basal levels of NA in the hippocampus were $0.52 \pm 0.08 \mathrm{~nm}$ in WT mice and $0.42 \pm 0.08 \mathrm{~nm}$ in STX1A ${ }^{-1-}$ mice. Basal levels of DA in the hippocampus were $0.31 \pm 0.05 \mathrm{~nm}$ in WT mice and $0.29 \pm$ $0.05 \mathrm{nM}$ in STX1A ${ }^{-1-}$ mice, and basal levels of 5-HT in the hippocampus of WT and STX1A ${ }^{-1-}$ mice were $0.67 \pm 0.08 \mathrm{nM}$ and $0.49 \pm 0.05 \mathrm{nM}$, respectively. There were no significant differences in basal monoamine levels among genotype. In microdialysis studies, $100 \mathrm{~mm} \mathrm{KCl}$ was perfused through the microdialysis probe into the hippocampus for $30 \mathrm{~min}$. High- $\mathrm{K}^{+}$-induced NA release was $270.4 \pm 35.5 \%$ baseline in WT mice and $142.1 \pm$ 6.5\%baseline in STX1A ${ }^{-1-}$ mice. High- $\mathrm{K}^{+}$-induced DA release was $371.6 \pm 33.5 \%$ baseline in WT mice and $215.0 \pm 28.3 \%$ baseline in STX1A ${ }^{-1-}$ mice. Stimulus-induced NA and DA release were significantly reduced in STX1A ${ }^{-1-}$ mice (Fig. $4 B, C$ ). High$\mathrm{K}^{+}$-induced 5-HT release was $1284.5 \pm 214.5 \%$ baseline in WT mice and $696.5 \pm 207.9 \%$ baseline in STX1A ${ }^{-1-}$ mice. Stimulusinduced 5-HT release showed a tendency to decrease in $\mathrm{STX} 1 \mathrm{~A}^{-1-}$ mice, but this decrease was not statistically significant $(p=0.06)$ (Fig. $4 D)$.

HPC-1/syntaxin 1A modulates the activity of NA transporters, 5-HT transporters, and DA transporters (Sung et al., 2003; Quick, 2003, 2006; Carvelli et al., 2008). To confirm whether deletion of HPC-1/syntaxin 1A affect NA and DA clearance, transporter function was assessed in WT and STX1A ${ }^{-1-}$ mice by synaptosomes prepared from whole brain (Table 2). NA transporter function was assessed by measuring $\left[{ }^{3} \mathrm{H}\right] \mathrm{NA}$ uptake. There were no significant differences in either $V_{\max }$ or $K_{\mathrm{m}}$, demonstrating that NA uptake activity is not altered in STX1A ${ }^{-1-}$ mice compared with WT mice. Similarly, DA transporter function was assessed in WT and STX1A ${ }^{-1-}$ mice by measuring $\left[{ }^{3} \mathrm{H}\right] \mathrm{DA}$ uptake. There were no significant differences in either $V_{\max }$ or $K_{\mathrm{m}}$, demonstrating that DA uptake activity is not altered in STX1A ${ }^{-1-}$ mice compared with WT mice. High-K ${ }^{+}(15 \mathrm{~mm} \mathrm{~K})$ stimulus-induced NA and DA release was further examined by synaptosomes prepared from whole brain (Table 2). Although there was no significant difference in basal NA release among genotypes, stimulus-induced NA release was significantly decreased in STX1A ${ }^{-1-}$ mice $(p<0.001)$. Similarly, stimulus-induced DA release was compared in WT and STX1A ${ }^{-1-}$ mice. Although there was no significant difference in basal DA re- 
A
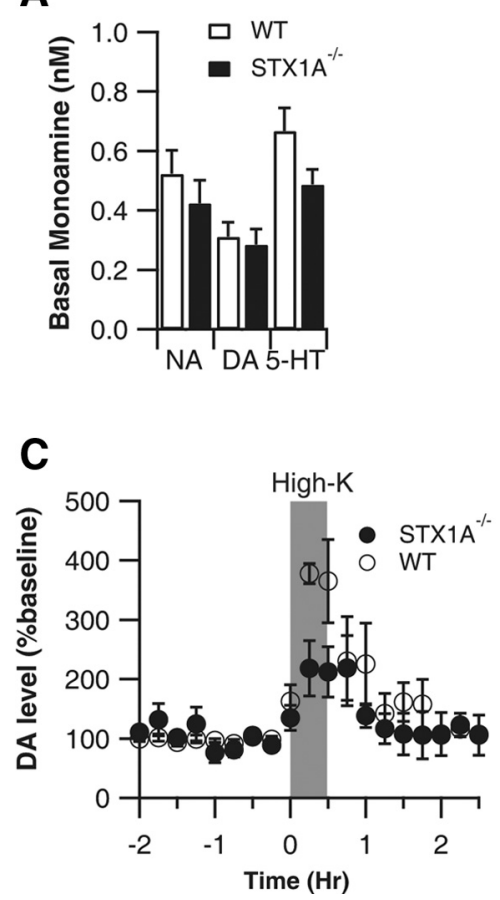

Figure 4. Basal and stimulation-induced monoamine release in the hippocampus. $\boldsymbol{A}$, Basal levels of monoamine release. Basal monoamine levels showed a tendency to decrease in STX1A ${ }^{-1-}$ mice, but the decrease was not statistically significant. $\boldsymbol{B}$, Effect of High- $\mathrm{K}^{+}$(100 mm, perfusion from microdialysis probe) on hippocampal NA levels. Time course of extracellular NA in the hippocampus. High- $\mathrm{K}^{+}$stimulation was delivered at time 0 for $30 \mathrm{~min}$. In STX1A ${ }^{-1-}$ mice $(n=4)$, High- $\mathrm{K}^{+}$was less effective in increasing hippocampal NA levels when compared with WT mice $(n=4)$. C, Effect of High- $K^{+}$on hippocampal DA levels. Time course of extracellular DA levels in the hippocampus. High- $K^{+}$stimulation was delivered at time 0 for 30 min. In STX1A ${ }^{-1-}$ mice $(n=3)$, High- $\mathrm{K}^{+}$was less effective in increasing hippocampal DA levels when compared with WT mice $(n=4)$. $D$, Effect of High- $\mathrm{K}^{+}$on hippocampal 5-HT levels. Time course of extracellular 5-HT in the hippocampus. High- $\mathrm{K}^{+}$stimulation was delivered at time 0 for $30 \mathrm{~min}$. High- $\mathrm{K}^{+}$-induced 5-HT release was not significantly different between WT $(n=5)$ and STX1A ${ }^{-1-}$ mice $(n=5)$.

Table 2. Catecholamine uptake and release in synaptosome

\begin{tabular}{|c|c|c|c|c|}
\hline & \multicolumn{2}{|l|}{ WT } & \multicolumn{2}{|l|}{ STX1A $^{-1-}$} \\
\hline & NA & $\mathrm{DA}$ & NA & $\mathrm{DA}$ \\
\hline \multicolumn{5}{|l|}{ Uptake } \\
\hline$K_{\mathrm{m}}(\mu \mathrm{M})$ & $4.26 \pm 0.16(4)$ & $5.38 \pm 0.02(4)$ & $6.58 \pm 2.18$ & $4.75 \pm 0.51(5)$ \\
\hline $\begin{array}{r}V_{\max }(\mathrm{pmol} / \mathrm{mg} \\
\text { protein } / \mathrm{min})\end{array}$ & $1.98 \pm 0.15(4)$ & $1.73 \pm 0.10(4)$ & $1.68 \pm 0.27(5)$ & $1.83 \pm 0.28(5)$ \\
\hline \multicolumn{5}{|l|}{ Release } \\
\hline Basal (\% total) & $3.78 \pm 0.29(9)$ & $4.71 \pm 0.23(9)$ & $3.68 \pm 0.20(9)$ & $5.11 \pm 0.24(9)$ \\
\hline $\begin{array}{l}15 \text { mм K } \\
\text { (\% total) }\end{array}$ & $9.93 \pm 0.29(9)$ & $9.02 \pm 0.74(9)$ & $8.17 \pm 0.14(9)^{* * * *}$ & $6.47 \pm 0.60(9)^{*}$ \\
\hline
\end{tabular}

Data shown are mean $\pm \mathrm{SE}(n) .{ }^{* * *} p<0.001,{ }^{*} p<0.05$.

lease among genotypes, stimulus-induced DA release was significantly decreased STX1A ${ }^{-1-}$ mice $(p<0.05)$.

We next examined the possibility that decreased levels of monoamine release are involved in LTP impairment in CA1 hippocampal slices. After a stable baseline response for $15 \mathrm{~min}$, NA $(10 \mu \mathrm{M})$ was bath-applied for $15 \mathrm{~min}$ before LTP induction. The application of NA persistently reduced the evoked response, which faded soon after drug washout in both WT and STX1A ${ }^{-1-}$ mice (Fig. 5A). NA enhanced the amplitude of LTP 50-60 min after TBS to $161.3 \pm 3.7 \%$ in STX1A ${ }^{-1-}$ mice $(p>0.9)$. In comparison, the induction of LTP was not affected in WT mice at 50-60 min $(p>0.4)$. The $\alpha_{1^{-}}, \alpha_{2^{-}}$and $\beta$-adrenergic receptor subtypes have been reported to be expressed in the CA1 region of the hippocampus. To examine which subtype of receptor is re- sponsible for enhancing LTP induction in STX1A ${ }^{-1-}$ mice, we used subtypeselective agonists to characterize the effect on LTP induction.

The application of the $\mathrm{G}_{\mathrm{s}}$-proteincoupled $\beta$-adrenergic receptor agonist isoproterenol (ISO; $1 \mu \mathrm{M}$ ) to hippocampal slices for 15 min slightly enhanced the synaptic response in the CA1 area (Fig. $5 B)$. The induction of LTP by TBS was significantly enhanced to $170.6 \pm 4.5 \%$ at 50-60 min by ISO in STX1A ${ }^{-1-}$ mice $(p>0.8)$, but was not further enhanced in WT mice $(p>0.8)(175.8 \pm 5.0 \%$ at 50-60 $\mathrm{min}$ ). To examine the requirement of the $\beta$-adrenergic receptor for the induction of LTP, we next tested whether blockade of the $\beta$-adrenergic receptor depressed induction of LTP in WT mice (Fig. 5C). The application of propranolol (1 $\mu \mathrm{M}$ ) alone, a $\beta$-adrenergic receptor antagonist, to hippocampal slices for $15 \mathrm{~min}$ had no effect on the induction of LTP in WT slices $(p>0.9)(172.3 \pm 3.3 \%$ at 50-60 min). Bath application of phenylephrine $(100 \mu \mathrm{M})$, an $\alpha_{1}$-adrenergic receptor agonist, or clonidine $(10 \mu \mathrm{M})$, an $\alpha_{2}$-adrenergic receptor agonist, for 15 min before TBS significantly suppressed LTP induction in WT mice, but it had no effect on the induction of LTP in STX1A ${ }^{-1-}$ slices (data not shown).

The application of DA $(10 \mu \mathrm{M})$ to hippocampal slices for 15 min slightly enhanced the synaptic response in the CA1 area (Fig. $6 A$ ). The induction of LTP by TBS was significantly enhanced to $171.7 \pm 8.0 \%$ at $50-60$ min by DA in STX1A ${ }^{-1-}$ mice $(p>0.8)$, but was not further enhanced in WT mice $(p>0.4)(186.3 \pm 2.1 \%$ at $50-60 \mathrm{~min})$. After observing that treatment with DA enhanced LTP induction in STX1A ${ }^{-1-}$ mice, we then examined the requirement of $\mathrm{G}_{\mathrm{s}}{ }^{-}$ protein-coupled D1/D5 receptors for LTP induction in WT mice. The application of the $\mathrm{G}_{\mathrm{s}}$-protein-coupled D1/D5 receptor agonist SKF38393 $(20 \mu \mathrm{M})$ to hippocampal slices for 15 min slightly enhanced the synaptic response in the CA1 area (Fig. $6 \mathrm{~B}$ ). The induction of LTP by TBS was significantly enhanced to $187.9 \pm$ $6.3 \%$ at $50-60$ min by SKF38393 in STX1A ${ }^{-1-}$ mice $(p>0.2)$, but was not further enhanced in WT mice $(p>0.4)(185.3 \pm$ $3.4 \%$ at $50-60 \mathrm{~min})$. As shown in Figure $6 C$, the application of the D1/D5 receptor antagonist $\mathrm{SCH} 23390(0.5 \mu \mathrm{M})$ to hippocampal slices for $15 \mathrm{~min}$ had no effect on the induction of LTP in WT slices $(p>0.6)(166.0 \pm 2.6 \%$ at $50-60 \mathrm{~min})$. We next examined the effect of 5-HT on LTP induction. The application of 5-HT had no effect on LTP induction in STX1A ${ }^{-1-}$ slices compared with control STX1A ${ }^{-1-}$ slices $(p<0.01)$, while induction of LTP was significantly suppressed in WT slices to levels seen in STX1A $^{-1-}$ slices following 5-HT application $(p<0.01)$ (data not shown).

Blockade of $\beta$-adrenergic or dopaminergic D1/D5 receptors were not alone sufficient for reduction of LTP induction and maintenance in WT mice. If STX1A ${ }^{-1-}$ mice showed impairment in exocytosis of dense-core vesicles, both adrenergic and dopaminergic systems could be affected. To confirm this possi- 
A

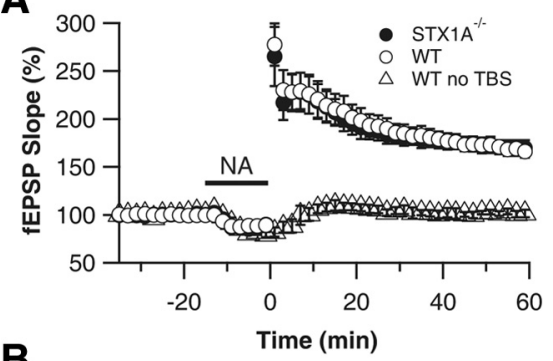

B
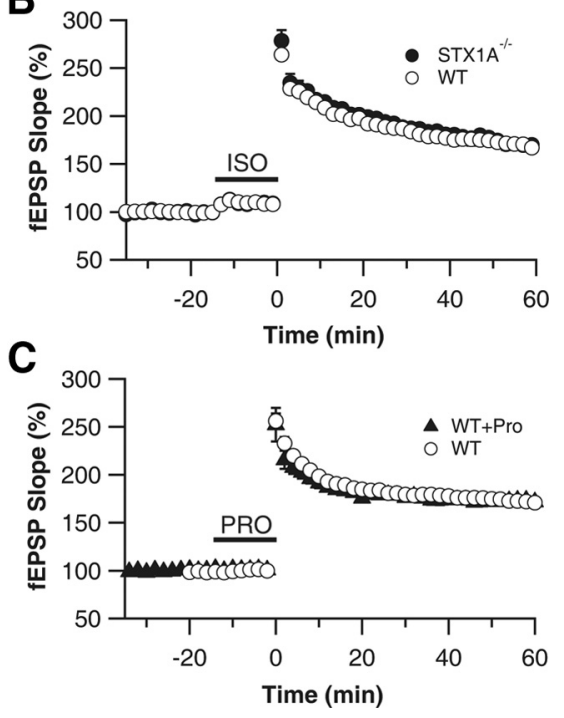

Figure 5. Effect of noradrenergic receptor activation on LTP. A, Bath application of NA (10 $\mu \mathrm{M})$ enhanced LTP induction and maintenance in STX1A ${ }^{-1-}$ mice $(n=9)$, but had no effect in WT mice $(n=13)$. NA was bath-applied for 15 min before LTP induction. NA alone did not elicit lasting potentiation $(n=3)$. The mean slope of fEPSPs recorded $0-20$ min before the application of NA was taken as $100 \%$. B, Bath application of ISO $(1 \mu \mathrm{m})$ enhanced LTP induction and maintenance in STX1A ${ }^{-1-}$ mice $(n=7)$, but had no effect in WT mice $(n=6)$. The mean slope of fEPSPs recorded $0-20 \mathrm{~min}$ before the application of ISO was taken as $100 \%$. C, Blockade of adrenergic $\beta$-receptor by bath application of propranolol (PRO; $1 \mu \mathrm{m}$ ) alone was insufficient to reduce LTP induction and maintenance in WT mice $(n=4)$. The mean slope of fEPSPs recorded $0-20$ min before the application of PRO was taken as $100 \%$.

bility, we then induced LTP under conditions of catecholamine depletion by 3-Iodo-L-tyrosine (3IT), a tyrosine hydroxylase inhibitor. Short-term bath application of 3IT $(250 \mu \mathrm{M})$ induced sustained depression of basal activity $(82.7 \pm 1.1 \%$ at $50-60$ $\mathrm{min})$, but had no effect on LTP induction in WT mice $(p>0.2)$ (Fig. $7 A ; 174.7 \pm 24.1 \%$ at $50-60 \mathrm{~min}$ ). Whereas long-term bath application of 3IT reduced LTP induction, even after robust presynaptic stimulation (12 bursts of TBS were provided twice at 20 -s intervals) was applied in WT mice $(p<0.01)$ (Fig. $7 B$; $147.8 \pm 5.5 \%$ at $50-60 \mathrm{~min}$ ). Under these conditions, 3IT was bath-applied for at least $2 \mathrm{~h}$ before LTP induction and during recording. We confirmed that levels of NA and DA, but not 5-HT, in hippocampal slices were significantly reduced by this long-term application of 3IT (Fig. 7C). Under conditions of catecholamine depletion, additional application of NA $(p>0.2)$ or DA $(p>0.7)$ for $15 \mathrm{~min}$ before TBS addition to the bath solution rescued LTP induction (Fig. $7 D$; NA, $192.1 \pm 7.3 \%$ at $50-60$; DA, $188.4 \pm 17.9 \%$ at $50-60)$. The above results showed that the exogenous application of catecholamine restored the induction of LTP under catecholamine depleted conditions. To examine whether induction of LTP is restored by enhancing endogenous catecholamine in the slice, we applied NA or a DA selective reuptake inhibitor. We found that application of desipramine, a
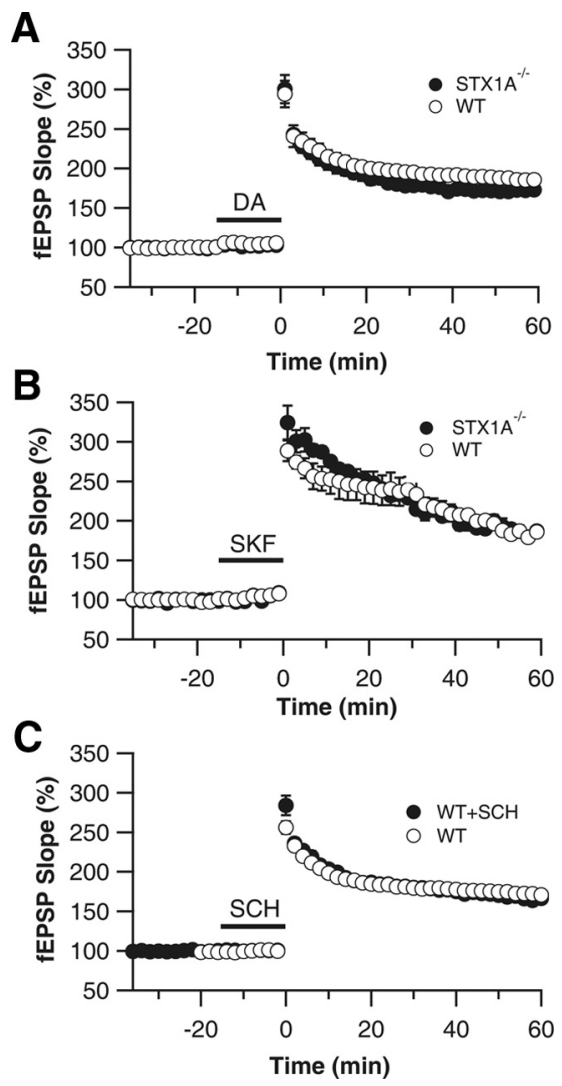

Figure 6. Effect of dopaminergic receptor activation on LTP. A, Bath application of DA (10 $\mu \mathrm{M})$ enhanced LTP induction and maintenance in STX1A ${ }^{-1-}$ mice $(n=5)$, but had no effect in WT mice $(n=10)$. DA was bath-applied for $15 \mathrm{~min}$ before LTP induction. The mean slope of fEPSPs recorded $0-20$ min before the application of DA was taken as $100 \%$. B, Bath application of SKF38393 (SKF; $20 \mu \mathrm{M}$ ) enhanced LTP induction and maintenance in STX1A ${ }^{-1-}$ mice $(n=$ $4)$, but had no effect in WT mice $(n=4)$. The mean slope of fEPSPs recorded $0-20$ min before the application of ISO was taken as $100 \%$. C, Blockade of dopaminergic D1 receptors by bath application of $\mathrm{SCH} 23390(\mathrm{SCH} ; 10 \mu \mathrm{m})$ alone was insufficient to reduce LTP induction and maintenance in WT mice $(n=6)$. The mean slope of fEPSPs recorded $0-20$ min before the application of SCH was taken as 100\%.

NA reuptake inhibitor, to hippocampal slices for $15 \mathrm{~min}$ enhanced induction of LTP by TBS to $174.7 \pm 4.2 \%$ at $50-60 \mathrm{~min}$ in STX1A ${ }^{-1-}$ mice $(p>0.8$ ) (Fig. $8 A)$, but did not enhance induction of LTP by TBS in WT mice $(p>0.8)(180.0 \pm 7.5 \%$ at 50-60 min). Application of GBR12935, a DA reuptake inhibitor, to hippocampal slices for $15 \mathrm{~min}$ also enhanced induction of LTP by TBS to $181.9 \pm 5.2 \%$ at $50-60 \mathrm{~min}$ in STX1A ${ }^{-1-}$ mice $(p>$ $0.7)$ (Fig. $8 B)$, but did not in WT mice by TBS $(p>0.9)(174.5 \pm$ $6.9 \%$ at $50-60 \mathrm{~min})$.

\section{Discussion}

The present study was designed to investigate the neural function of HPC-1/syntaxin $1 \mathrm{~A}$ in synaptic plasticity. HPC-1/syntaxin 1A operates as a neuronal t-SNARE (target SNARE) to form a SNARE complex by interacting with SNAP-25 and VAMP2/synaptobrebin in synaptic transmission. The deletion of SNAP-25 or VAMP2/synaptobrebin causes a severe reduction in evoked synaptic transmission in mouse central synapses (Schoch et al., 2001; Washbourne et al., 2002). We previously found that STX1A ${ }^{-1-}$ mice exhibited normal fast synaptic transmission using cultured hippocampal neurons (Fujiwara et al., 2006). Moreover, in this study, we found no significant differences in fast synaptic transmission via clear synaptic vesicles, alterations in the input-output 
A
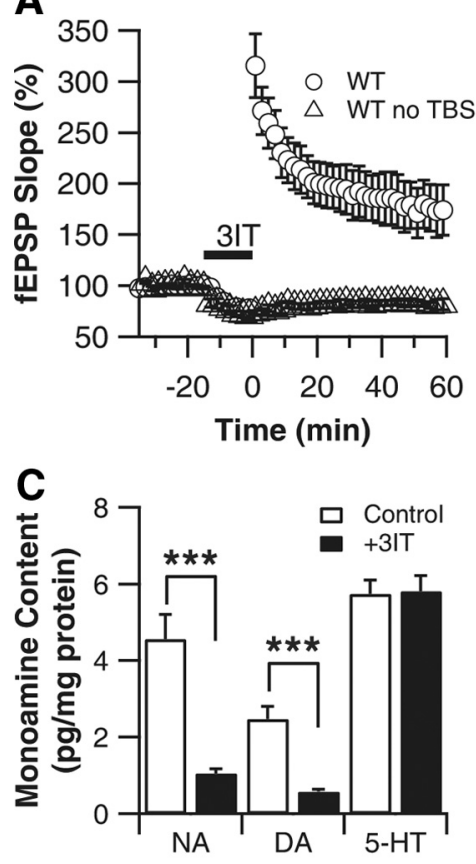

B
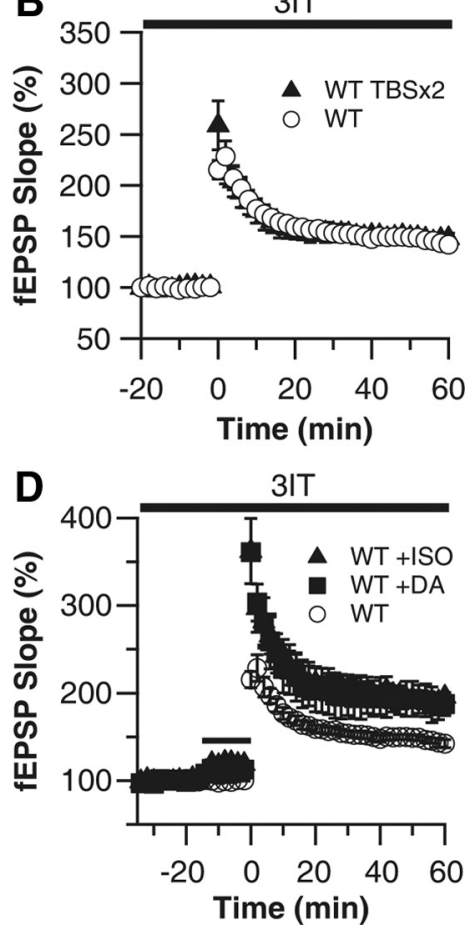

Figure 7. Inhibition of tyrosine hydroxylase causes reduction of LTP in the CA1 area. $A$, Bath application of 3 IT (250 $\mu \mathrm{M})$, a tyrosine hydroxylase inhibitor, induced sustained depression of basal activity $(n=6)$, but had no effect on LTP induction and maintenance $(n=6)$. 3IT was bath-applied for $15 \mathrm{~min}$ before LTP induction. $\boldsymbol{B}$, Long-term application of 3IT reduced LTP induction by TBS $(n=9)$, even after robust presynaptic stimulation was applied in WT mice (TBS, 2 times; $n=4)$. C, NA $(n=11)$ and DA levels $(n=15)$, but not 5 -HT levels $(n=15)$ in hippocampal slices were significantly reduced by long-term application of 3IT. D, 3IT was bath-applied for at least $2 \mathrm{~h}$ before LTP induction and during recording. Additional application of ISO $(1 \mu \mathrm{M})(n=4)$ or DA $(10 \mu \mathrm{m})(n=5)$ to the bath solution rescued LTP induction by TBS in WT mice. ${ }^{* * *} p<0.001$.
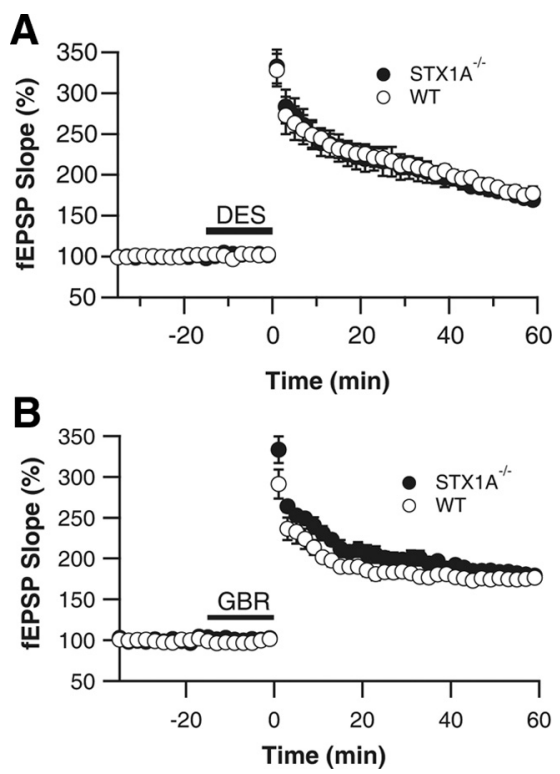

Figure 8. Endogenous catecholamine activation enhanced LTP. A, Bath application of desipramine (DES; $0.1 \mu \mathrm{M}$ ) enhanced LTP induction and maintenance by TBS in STX1A ${ }^{-1-}$ mice $(n=5)$, but had no effect in WT mice $(n=5)$. DES was bath-applied for 15 min before LTP induction. The mean slope of $f E P S P$ s recorded $0-20$ min before the application of DES was taken as $100 \%$. B, Bath application of GBR12935 (GBR; $0.1 \mu \mathrm{M})$ enhanced LTP induction and maintenance by TBS in STX1A ${ }^{-1-}$ mice $(n=5)$, but had no effect in WT mice $(n=5)$. The mean slope of fEPSPs recorded $0-20 \mathrm{~min}$ before the application of GBR was taken as $100 \%$. curve, paired-pulse plasticity, or significantly modified local circuit properties in response to high-frequency bursts between hippocampal slices of both genotypes. These results indicate that HPC-1/ syntaxin $1 \mathrm{~A}$ is not essential for fast synaptic transmission or that its functions may be compensated for by other proteins. Syntaxin $1 \mathrm{~B}$ is the most reasonable candidate for such a substitution. The two syntaxin isoforms, HPC-1/syntaxin $1 \mathrm{~A}$ and syntaxin $1 \mathrm{~B}$, are expressed in a combinatorial manner in the central and peripheral nervous system, with some regions of overlap (RuizMontasell et al., 1996; Aguado et al., 1999). Genetic defects in HPC-1/syntaxin 1A did not change the syntaxin $1 \mathrm{~B}$ content or the expression of other exocytosis-related proteins (Fujiwara et al., 2006), indicating a reduction in the total amount of syntaxin 1 and the downregulation of exocytotic function. Although it does not seem to be remarkable for fast synaptic transmission, this change may affect synaptic plasticity. The physiological significance of the occurrence of these two isoforms and their differential distribution remains to be elucidated.

Although induction of LTP at excitatory synapses in the CA1 region of the hippocampus is primarily dependent on the activation of NMDA-type glutamate receptors (Bliss et al., 2006), neuromodulators such as NA (Katsuki et al., 1997; Thomas et al., 1996), DA (Huang and Kandel, 1995) and 5-HT (Normann and Clark, 2005) strongly influence the process as well. Monoaminergic involvement of LTP induction and maintenance is also supported by reports that have measured the concentrations and temporal dynamics of such neuromodulators during LTP (Frey et al., 1990; Harley, 1991; Bronzino et al., 2001). These reports showed that local NA and DA concentrations could rise to several times the basal value upon tetanus stimulation during induction of LTP. HPC-1/syntaxin 1A is involved in monoaminergic neurotransmission by regulating exocytosis of dense-core synaptic vesicles. In this study, monoamine release induced by high- $\mathrm{K}^{+}$ stimulation was decreased in STX1A ${ }^{-1-}$ mice, although the content of catecholamine in hippocampal slices did not differ between genotypes (Fig. 4, Table 2). These results suggest that absence of HPC-1/syntaxin 1A disrupts the monoaminergic system during LTP induction. This finding is further supported by a report that showed abnormal glucose-stimulated release of insulin from pancreatic $\beta$ cells of STX1A ${ }^{-1-}$ mice (Ohara-Imaizumi et al., 2007). Insulin release displays a biphasic pattern, a rapidly initiated and transient first phase preceding a sustained second phase in WT $\beta$-cells. However, STX1A ${ }^{-1-} \beta$-cells showed fewer previously docked granules with no fusion during the first phase, while second-phase fusion was preserved.

NA modulates synaptic function via the activation of G-protein-coupled adrenergic receptors, including $\alpha_{1}-, \alpha_{2}$ - and $\beta$-receptors. We found that the application of NA or ISO caused no further enhancement of LTP amplitude in WT mice. $\beta$-Adrenoceptor activation by ISO has previously been reported to be ineffective in LTP in response to four trains of high- 
frequency stimulation (Gelinas et al., 2008). Several studies have shown that the activation of $\beta$-adrenoceptors selectively enhances the induction and maintenance of LTP in response to weak, subthreshold synaptic stimulation (Thomas et al., 1996; Katsuki et al., 1997). DA also enhances the induction and maintenance of LTP via postsynaptic D1/D5 receptors (Otmakhova and Lisman, 1996; Swanson-Park et al., 1999; Navakkode et al., 2007; Sajikumar et al., 2008) by lowering the stimulus strength required for the induction of LTP (Swanson-Park et al., 1999; Li et al., 2003). DA and NA postsynaptically activate adenylate cyclase through their D1/D5- or $\beta$-adrenergic receptors, respectively. This activation causes a transient increase in cAMP, which in turn activates PKA (Raman et al., 1996; Navakkode et al., 2010). Our study shows that impairments in LTP can be rescued by Fsk, a pharmacological activator of adenylyl cyclase. A relatively high concentration of Fsk $(50 \mu \mathrm{M})$ can induce LTP in response to low-frequency test stimulation typically used to monitor the strength of synapses (Otmakhov et al., 2004), indicating that sufficient activation of the cAMP/PKA signaling cascade can lower the stimulus strength required for LTP induction. The impairment of LTP at CA1 synapses in hippocampal slices prepared from STX1A ${ }^{-1-}$ mice was also rescued by increased stimulation. Because the decrease in release of endogenous catecholamine during TBS resulted in an increase in the stimulus strength required for LTP induction, it is reasonable that the robust LTP induction protocol can restore LTP in STX1A ${ }^{-1-}$ mice (Fig. 3B). Consistent with previous reports (Schimanski et al., 2007; Stramiello and Wagner, 2008), pharmacological blockade of $\beta$-adrenergic or dopaminergic D1/D5 receptors alone was not sufficient to reduce LTP amplitude, but we found that catecholamine depletion by long-term application of 3IT reduced LTP amplitude even after robust presynaptic stimulation in WT mice. These results indicate that postsynaptic adenylyl cyclase could be turned on sufficiently by alternate activation of $\beta$-adrenergic receptors or dopaminergic D1/D5 receptors, to lower the stimulus strength required for LTP induction. Indeed, we could restore LTP induction of STX1A ${ }^{-1-}$ mice not only by exogenously applied catecholamine but also by endogenously released catecholamine in the presence of a monoamine transporter antagonist such as desipramine and GBR12935. Together, these results strongly suggest that absence of STX1A ${ }^{-1-}$ reduces LTP amplitude at the CA1 synapse by disrupting catecholaminergic systems. Although HPC-1/syntaxin $1 \mathrm{~A}$ is involved in catecholaminergic neurotransmission, the underlying molecular mechanism remains poorly understood.

Memory storage and spatial learning induce LTP in CA1 synapses (Pastalkova et al., 2006; Whitlock et al., 2006). The neural circuitry of fear conditioning has been extensively studied and is thought to depend upon the hippocampus as well as the amygdala (LeDoux, 2000). Both neural areas were innervated by noradrenergic and dopaminergic pathways from the locus ceruleus and the ventral tegmental area, respectively. STX1A ${ }^{-1-}$ mice exhibited impaired consolidation of conditioned fear memory by weak training but not by strong training (Fujiwara et al., 2006). From this behavioral phenotype, we expect the relationship to impaired CA1 LTP induction, which could be restored by robust synaptic stimulation (Fig. 3B), because decreased catecholamine levels during LTP induction increase the stimulus strength required for LTP. This expectation is supported by studies that show adrenergic signaling in the hippocampus is critical for the retrieval of contextual and spatial memories (Murchison et al., 2004, 2011). To clarify the relationship between impaired synaptic plasticity and behavioral abnormalities in STX1A ${ }^{-1-}$ mice, additional behavioral analyses are needed.
In summary, HPC1/syntaxin 1A-null mice showed impairment of LTP maintenance and disruption of catecholamine release in the hippocampus. Recent reports have confirmed that NA and DA control the persistence of LTP in the CA1 (SwansonPark et al., 1999; Yang et al., 2002). Impaired LTP restored by activation of NA or DA receptors suggests the involvement of $\mathrm{HPC1} /$ syntaxin $1 \mathrm{~A}$ in the catecholaminergic system via exocytosis of dense-core synaptic vesicles.

\section{References}

Aguado F, Majó G, Ruiz-Montasell B, Llorens J, Marsal J, Blasi J (1999) Syntaxin $1 \mathrm{~A}$ and $1 \mathrm{~B}$ display distinct distribution patterns in the rat peripheral nervous system. Neuroscience 88:437-446.

Arai A, Lynch G (1992) Factors regulating the magnitude of long-term potentiation induced by theta pattern stimulation. Brain Res 598:173-184.

Bennett MK, Calakos N, Scheller RH (1992) Syntaxin: A synaptic protein implicated in docking of synaptic vesicles at presynaptic active zones. Science 257:255-259.

Bezprozvanny I, Scheller RH, Tsien RW (1995) Functional impact of syntaxin on gating of N-type and Q-type calcium channels. Nature 378:623-626

Bliss TV, Collingridge GL, Laroche S (2006) Neuroscience. ZAP and ZIP, a story to forget. Science 313:1058-1059.

Bronzino JD, Kehoe P, Mallinson K, Fortin DA (2001) Increased extracellular release of hippocampal NE is associated with tetanization of the medial perforant pathway in the freely moving adult male rat. Hippocampus 11:423-429.

Carvelli L, Blakely RD, DeFelice LJ (2008) Dopamine transporter/syntaxin $1 \mathrm{~A}$ interactions regulate transporter channel activity and dopaminergic synaptic transmission. Proc Natl Acad Sci U S A 105:14192-14197.

Degtiar VE, Scheller RH, Tsien RW (2000) Syntaxin modulation of slow inactivation of N-type calcium channels. J Neurosci 20:4355-4367.

Franklin KBJ, Paxinos G (1997) The mouse brain in stereotaxic coordinates. San Diego: Academic.

Frey U, Schroeder H, Matthies H (1990) Dopaminergic antagonists prevent long-term maintenance of posttetanic LTP in the CA1 region of rat hippocampal slices. Brain Res 522:69-75.

Fujiwara T, Yamamori T, Akagawa K (2001) Suppression of transmitter release by tat HPC-1/syntaxin 1A fusion protein. Biochim Biophys Acta 1539:225-232.

Fujiwara T, Mishima T, Kofuji T, Chiba T, Tanaka K, Yamamoto A, Akagawa K (2006) Analysis of knock-out mice to determine the role of HPC-1/ syntaxin 1A in expressing synaptic plasticity. J Neurosci 26:5767-5776.

Fujiwara T, Snada M, Kofuji T, Yoshikawa T, Akagawa K (2010) HPC-1/ syntaxin $1 \mathrm{~A}$ gene knockout mice show abnormal behavior possibly related to a disruption in 5-HTergic systems. Eur J Neurosci 32:99-107.

Gelinas JN, Tenorio G, Lemon N, Abel T, Nguyen PV (2008) Betaadrenergic receptor activation during distinct patterns of stimulation critically modulates the PKA-dependence of LTP in the mouse hippocampus. Learn Mem 15:281-289.

Harley C (1991) Noradrenergic and locus coeruleus modulation of the perforant path-evoked potential in rat dentate gyrus supports a role for the locus coeruleus in attentional and memorial processes. Prog Brain Res 88:307-321.

Huang YY, Kandel ER (1995) D1/D5 receptor agonists induce a protein synthesis-dependent late potentiation in the CA1 region of the hippocampus. Proc Natl Acad Sci U S A 92:2446-2450.

Inoue A, Obata K, Akagawa K (1992) Cloning and sequence analysis of cDNA for a neuronal cell membrane antigen, HPC-1. J Biol Chem 267:10613-10619.

Jarvis SE, Zamponi GW (2001) Distinct molecular determinants govern syntaxin 1A-mediated inactivation and G-protein inhibition of N-type calcium channels. J Neurosci 21:2939-2948.

Katsuki H, Izumi Y, Zorumski CF (1997) Noradrenergic regulation of synaptic plasticity in the hippocampal CA1 region. J Neurophysiol 77:3013-3020.

Kushima Y, Fujiwara T, Sanada M, Akagawa K (1997) Characterization of HPC-1 antigen, an isoform of syntaxin-1, with the isoform-specific monoclonal antibody, 14D8. J Mol Neurosci 8:19-27.

LeDoux JE (2000) Emotion circuits in the brain. Annu Rev Neurosci 23:155-184. 
Li S, Cullen WK, Anwyl R, Rowan MJ (2003) Dopamine-dependent facilitation of LTP induction in hippocampal CA1 by exposure to spatial novelty. Nat Neurosci 6:526-531.

Lin RC, Scheller RH (2000) Mechanisms of synaptic vesicle exocytosis. Annu Rev Cell Dev Biol 16:19-49.

Lisman J (2003) Long-term potentiation: Outstanding questions and attempted synthesis. Philos Trans R Soc Lond B Biol Sci 358:829-842.

Mishima T, Fujiwara T, Akagawa K (2002) Reduction of neurotransmitter release by the exogenous $\mathrm{H} 3$ domain peptide of $\mathrm{HPC}-1$ /syntaxin $1 \mathrm{~A}$ in cultured rat hippocampal neurons. Neurosci Lett 329:273-276.

Mochida S, Sheng ZH, Baker C, Kobayashi H, Catterall WA (1996) Inhibition of neurotransmission by peptides containing the synaptic protein interaction site of N-type $\mathrm{Ca}^{2+}$ channels. Neuron 17:781-788.

Murchison CF, Zhang XY, Zhang WP, Ouyang M, Lee A, Thomas SA (2004) A distinct role for norepinephrine in memory retrieval. Cell 117:131-143.

Murchison CF, Schutsky K, Jin SH, Thomas SA (2011) Norepinephrine and $s s(1)$-adrenergic signaling facilitate activation of hippocampal CA1 pyramidal neurons during contextual memory retrieval. Neuroscience 181:109-116.

Navakkode S, Sajikumar S, Frey JU (2007) Synergistic requirements for the induction of dopaminergic D1/D5-receptor-mediated LTP in hippocampal slices of rat CA1 in vitro. Neuropharmacology 52:1547-1554.

Navakkode S, Sajikumar S, Sacktor TC, Frey JU (2010) Protein kinase mzeta is essential for the induction and maintenance of dopamine-induced long-term potentiation in apical CA1 dendrites. Learn Mem 17:605-611.

Nguyen PV, Kandel ER (1997) Brief theta-burst stimulation induces a transcription-dependent late phase of LTP requiring cAMP in area CA1 of the mouse hippocampus. Learn Mem 4:230-243.

Normann C, Clark K (2005) Selective modulation of ca(2+) influx pathways by 5 -HT regulates synaptic long-term plasticity in the hippocampus. Brain Res 1037:187-193.

Ohara-Imaizumi M, Fujiwara T, Nakamichi Y, Okamura T, Akimoto Y, Kawai J, Matsushima S, Kawakami H, Watanabe T, Akagawa K, Nagamatsu S (2007) Imaging analysis reveals mechanistic differences between first- and second-phase insulin exocytosis. J Cell Biol 177:695-705.

Otmakhov N, Khibnik L, Otmakhova N, Carpenter S, Riahi S, Asrican B, Lisman J (2004) Forskolin-induced LTP in the CA1 hippocampal region is NMDA receptor dependent. J Neurophysiol 91:1955-1962.

Otmakhova NA, Lisman JE (1996) D1/D5 dopamine receptor activation increases the magnitude of early long-term potentiation at CA1 hippocampal synapses. J Neurosci 16:7478-7486.

Otmakhova NA, Otmakhov N, Mortenson LH, Lisman JE (2000) Inhibition of the cAMP pathway decreases early long-term potentiation at CA1 hippocampal synapses. J Neurosci 20:4446-4451.

Parsons LH, Justice JB Jr (1992) Extracellular concentration and in vivo recovery of dopamine in the nucleus accumbens using microdialysis. J Neurochem 58:212-218.

Pastalkova E, Serrano P, Pinkhasova D, Wallace E, Fenton AA, Sacktor TC (2006) Storage of spatial information by the maintenance mechanism of LTP. Science 313:1141-1144.

Patterson SL, Pittenger C, Morozov A, Martin KC, Scanlin H, Drake C, Kandel ER (2001) Some forms of cAMP-mediated long-lasting potentiation are associated with release of BDNF and nuclear translocation of phospho-MAP kinase. Neuron 32:123-140.

Quick MW (2003) Regulating the conducting states of a mammalian serotonin transporter. Neuron 40:537-549.
Quick MW (2006) The role of SNARE proteins in trafficking and function of neurotransmitter transporters. Handb Exp Pharmacol:181-196.

Raman IM, Tong G, Jahr CE (1996) Beta-adrenergic regulation of synaptic NMDA receptors by cAMP-dependent protein kinase. Neuron 16:415-421.

Rizo J, Südhof TC (2002) Snares and Munc18 in synaptic vesicle fusion. Nat Rev Neurosci 3:641-653.

Ruiz-Montasell B, Aguado F, Majó G, Chapman ER, Canals JM, Marsal J, Blasi J (1996) Differential distribution of syntaxin isoforms 1A and 1B in the rat central nervous system. Eur J Neurosci 8:2544-2552.

Sajikumar S, Navakkode S, Frey JU (2008) Distinct single but not necessarily repeated tetanization is required to induce hippocampal late-LTP in the rat CA1. Learn Mem 15:46-49.

Schimanski LA, Ali DW, Baker GB, Nguyen PV (2007) Impaired hippocampal LTP in inbred mouse strains can be rescued by beta-adrenergic receptor activation. Eur J Neurosci 25:1589-1598.

Schoch S, Deák F, Königstorfer A, Mozhayeva M, Sara Y, Südhof TC, Kavalali ET (2001) SNARE function analyzed in synaptobrevin/VAMP knockout mice. Science 294:1117-1122.

Söllner T, Bennett MK, Whiteheart SW, Scheller RH, Rothman JE (1993) A protein assembly-disassembly pathway in vitro that may correspond to sequential steps of synaptic vesicle docking, activation, and fusion. Cell 75:409-418.

Staubli U, Otaky N (1994) Serotonin controls the magnitude of LTP induced by theta bursts via an action on NMDA-receptor-mediated responses. Brain Res 643:10-16.

Stramiello M, Wagner JJ (2008) D(1/5) receptor-mediated enhancement of LTP requires PKA, src family kinases, and NR2B-containing NMDARs. Neuropharmacology 55:871-877.

Sung U, Apparsundaram S, Galli A, Kahlig KM, Savchenko V, Schroeter S, Quick MW, Blakely RD (2003) A regulated interaction of syntaxin 1A with the antidepressant-sensitive norepinephrine transporter establishes catecholamine clearance capacity. J Neurosci 23:1697-1709.

Swanson-Park JL, Coussens CM, Mason-Parker SE, Raymond CR, Hargreaves EL, Dragunow M, Cohen AS, Abraham WC (1999) A double dissociation within the hippocampus of dopamine D1/D5 receptor and beta-adrenergic receptor contributions to the persistence of long-term potentiation. Neuroscience 92:485-497.

Thomas MJ, Moody TD, Makhinson M, O’Dell TJ (1996) Activitydependent beta-adrenergic modulation of low frequency stimulation induced LTP in the hippocampal CA1 region. Neuron 17:475-482.

Washbourne P, Thompson PM, Carta M, Costa ET, Mathews JR, LopezBenditó G, Molnár Z, Becher MW, Valenzuela CF, Partridge LD, Wilson MC (2002) Genetic ablation of the t-SNARE SNAP-25 distinguishes mechanisms of neuroexocytosis. Nat Neurosci 5:19-26.

Whitlock JR, Heynen AJ, Shuler MG, Bear MF (2006) Learning induces long-term potentiation in the hippocampus. Science 313:1093-1097.

Xu T, Rammner B, Margittai M, Artalejo AR, Neher E, Jahn R (1999) Inhibition of SNARE complex assembly differentially affects kinetic components of exocytosis. Cell 99:713-722.

Yamaguchi K, Takada M, Fujimori K, Tsuchimoto Y, Kushima Y, Sanada M, Fujiwara T, Akagawa K (1997) Enhancement of synaptic transmission by HPC-1 antibody in the cultured hippocampal neuron. Neuroreport 8:3641-3644

Yang HW, Lin YW, Yen CD, Min MY (2002) Change in bi-directional plasticity at CA1 synapses in hippocampal slices taken from 6-hydroxydopaminetreated rats: the role of endogenous norepinephrine. Eur J Neurosci 16:11171128 . 